\title{
Paying for pensions and other public expenditures : overtaxing our children?
}

Citation for published version (APA):

Sebald, A., \& de Neubourg, C. R. J. (2003). Paying for pensions and other public expenditures : overtaxing our children? METEOR, Maastricht University School of Business and Economics. METEOR Research Memorandum No. 052 https://doi.org/10.26481/umamet.2003052

Document status and date:

Published: 01/01/2003

DOI:

10.26481/umamet.2003052

Document Version:

Publisher's PDF, also known as Version of record

\section{Please check the document version of this publication:}

- A submitted manuscript is the version of the article upon submission and before peer-review. There can be important differences between the submitted version and the official published version of record.

People interested in the research are advised to contact the author for the final version of the publication, or visit the DOI to the publisher's website.

- The final author version and the galley proof are versions of the publication after peer review.

- The final published version features the final layout of the paper including the volume, issue and page numbers.

Link to publication

\footnotetext{
General rights rights.

- You may freely distribute the URL identifying the publication in the public portal. please follow below link for the End User Agreement:

www.umlib.nl/taverne-license

Take down policy

If you believe that this document breaches copyright please contact us at:

repository@maastrichtuniversity.nl

providing details and we will investigate your claim.
}

Copyright and moral rights for the publications made accessible in the public portal are retained by the authors and/or other copyright owners and it is a condition of accessing publications that users recognise and abide by the legal requirements associated with these

- Users may download and print one copy of any publication from the public portal for the purpose of private study or research.

- You may not further distribute the material or use it for any profit-making activity or commercial gain

If the publication is distributed under the terms of Article $25 \mathrm{fa}$ of the Dutch Copyright Act, indicated by the "Taverne" license above, 


\title{
Paying for Pensions and Other Public Expenditures: Overtaxing our Children?*
}

\author{
Alexander C. Sebald and Chris de Neubourg \\ University of Maastricht ${ }^{\dagger}$
}

December 18, 2003

\begin{abstract}
This paper argues that although current public pension schemes may shift the major financial burden to future generations, private and public transfers of wealth across generations offset this development. As a result the financing of existing social security and pension arrangements seems to be less problematic than commonly assumed.

Policy models that assume there is no linkage between generations except through the state bear little resemblance to empirical reality. An accounting system is therefore needed which highlights the allocation of retirement costs among working and retired population as well as future generations, and includes the public as well as private ledger.

Many of the aformentioned features are included in the well-established practice of 'Generational Accounting'. This paper, however, will integrate private as well as public intergenerational transfers of wealth so as to account not only for the burden, which current generations leave, but also the wealth, which is passed on to future generations.
\end{abstract}

\section{Introduction}

Generational Accounting' was developed in order to unfold the 'long-term' fiscal stance of governments.[12] In contrast to the traditional budgetary approach, it is based on the life-cycle hypothesis, which means it evaluates the financial burden, which current and future generations face, based on lifetime taxes paid and lifetime transfers received.[1] 'Generational Accounting' had a decisive impact on the pension debate, since its empirical application to many countries led to the conclusion that future generations are seriously overtaxed, if current provisions are not revised. Taking account of the unprecedented demographic

\footnotetext{
${ }^{*}$ We would like to thank Georg Kirchsteiger and Laurence Kotlikoff for their constructive comments on an earlier draft. All remaining errors are ours.

†University of Maastricht, Department of Economics, Tongersestraat 53, Postbus 616, 6200 MD Maastricht, The Netherlands, E.mail: a.sebald@algec.unimaas.nl; c.deneubourg@algec.unimaas.nl
} 
transition at the beginning of the 21st century in most of the advanced countries, 'Generational Accounting' questions the fiscal sustainability of the current social security- and pension arrangements stating that the burden on future generations is actually so overwhelming that current arrangements are unsustainable and that there is no other choice than to drastically alter current institutional arrangements. $^{1}$

This paper challenges the latter view by arguing that if private transfers across generations are taken into account within a 'Generational Accounting' framework, the picture is far less gloomy since future generations are not only left with the burden of the current expenditures to be financed, but also with a considerable stock of wealth. This may sound comfortable; it leaves, however, both serious policy- and theoretical questions to be addressed. The policy questions relate to distributional issues, taxability and the allocation of the tax burden; the theoretical questions, on the other hand, refer to the relationship between altruistic behaviour, the life-cycle model of consumption and the Ricardian equivalence theorem.

Ever since Adam Smith published 'The Wealth of Nations' the appropriate size of governments has been at the heart of political discussions. Traditionally much of this debate has centred on the public debt due to its alleged harmful correlation with interest rates, national savings, economic growth and current account deficits. [8] In the last decades this neoclassical view has been challenged, however, by the Ricardian equivalence theorem, which is based on the assumption that altruistic economic agents fully internalise the budget constraint of their descendants. [2] In contrast to the neoclassical view, the Ricardian equivalence therefore states that private households conceive debt financed public expenditures as higher taxes in the future, which induces them to increase their savings to enable future generations to pay for them. Consequently national saving is not reduced, there is no effect on the interest rate and therefore also no effect on the capital stock and economic growth in the future.

However, it is not only the alleged harmful effect of the public debt, but also its definition, which is a source of controversy. Many believe that the impact of fiscal policies on today's economy and the burden, which is being placed on future generations, is not adequately measured by simple government debt figures. In response 'Generational Accounting' was developed.

In line with earlier publications this paper argues that the forward-looking life-cycle perspective implicit in 'Generational Accounting' represents a change of paradigm in the definition of the public debt and consequently offers a more accurate picture of the sustainability of today's fiscal policies (section 2).

It is however also argued that 'Generational Accounting' does not resolve the first debate hinted at above about the impact, which the public debt has, on the economy and future generations. More specifically, it will be shown with data

\footnotetext{
${ }^{1}$ Strictly speaking 'Generational Accounting' looks at the entire public ledger. As however social security and pension systems constitute the largest share in the government budget in most industrialised countries, their future financial situation decisively influences the conclusions drawn from it.
} 
for the UK, that the sole concentration on the public ledger in the context of the traditional methodology of 'Generational Accounting' results in misleading conclusions regarding the intergenerational impact of fiscal policies as soon as decision horizons differ from the strict life-cycle model (section 3).

Despite the policy relevance of this conclusion, it does not solve the question about the interpretation of shifts in transfers and taxes between generations or in other words, about the validity of the Ricardian equivalence theorem. Therefore, the interpretative limitations of our approach and the theoretical issues raised will be further discussed in the concluding paragraph (section 4).

\section{The original methodology}

Although the concept of the government debt is the most widely used indicator to measure the intergenerational impact of fiscal policies in neoclassical theory, its conceptual framework is a long-debated topic in economics. It has been argued that the traditional budgetary approach is an inappropriate indicator to measure the intergenerational distribution of the public burden, as it is only based on the annual equation of public revenues and expenditures. It therefore fails to include the long-term revenue and expenditure implications of present fiscal policies, which are relevant when economic agents make economic decisions with a life-cycle perspective.[1]

As said in the introduction, 'Generational Accounting', which has been developed as a reaction to these criticisms, contains this life-cycle approach by starting from the intertemporal government budget constraint.

$$
\begin{aligned}
\sum_{s=t}^{\infty} G_{s}\left(1+r_{s}\right)^{t-s}= & {\left[\sum_{s=t}^{k+D} L_{s, k} n_{s, k}\left(1+r_{s}\right)^{t-s}-\sum_{s=t}^{k+D} L_{s, k} p_{s, k}\left(1+r_{s}\right)^{t-s}\right]+} \\
& {\left[\sum_{s=t+1}^{\infty} L_{s, k} n_{s, k}\left(1+r_{s}\right)^{t-s}-\sum_{s=t+1}^{\infty} L_{s, k} p_{s, k}\left(1+r_{s}\right)^{t-s}\right]+W_{t}^{g} }
\end{aligned}
$$

Note

$t=$ Base year

$G_{s}=$ Government spending in all current and future periods $s$

$L_{s, k}=$ Population of generation $k$ in all current and future periods $s$

$p_{s, k}=$ Avg benefit receipt of generation $k$ in all current and future periods $s$

$n_{s, k}=$ Avg tax payments of generation $k$ in all current and future periods $s$

$D=$ Maximum age

$r_{s}=$ Interest rate in all current and future periods $s$

$W_{t}^{g}=$ Government wealth in the base year $t$ 
The intertemporal budget constraint of the government states that all current and future purchases by the government $\left(\sum_{s=t}^{\infty} G_{s}\left(1+r_{s}\right)^{t-s}\right)$ have to be financed either through the remaining net tax payments of currently living generations $\left(\left[\sum_{s=t}^{k+D} L_{s, k} n_{s, k}\left(1+r_{s}\right)^{t-s}-\sum_{s=t}^{k+D} L_{s, k} p_{s, k}\left(1+r_{s}\right)^{t-s}\right]\right)$, the net wealth of the government $\left(W_{t}^{g}\right)$ or the tax payments of future generations $\left(\left[\sum_{s=t+1}^{\infty} L_{s, k} n_{s, k}\left(1+r_{s}\right)^{t-s}-\sum_{s=t+1}^{\infty} L_{s, k} p_{s, k}\left(1+r_{s}\right)^{t-s}\right]\right)$. The intergenerational imbalance is, consequently, calculated assuming that future generations have to finance all government bills that have been left uncovered by generations already alive in the base year $t$. Hence, mathematically the aggregate financial burden that future generations have to bear is defined as the residual of the other three components of the intertemporal budget constraint.

$$
\begin{aligned}
& \sum_{s=t}^{\infty} G_{s}\left(1+r_{s}\right)^{t-s}-\left[\sum_{s=t}^{k+D} L_{s, k} n_{s, k}\left(1+r_{s}\right)^{t-s}-\sum_{s=t}^{k+D} L_{s, k} p_{s, k}\left(1+r_{s}\right)^{t-s}\right]-W_{t}^{g} \\
& =\left[\sum_{s=t+1}^{\infty} L_{s, k} n_{s, k}\left(1+r_{s}\right)^{t-s}-\sum_{s=t+1}^{\infty} L_{s, k} p_{s, k}\left(1+r_{s}\right)^{t-s}\right]
\end{aligned}
$$

In order to unfold the intergenerational impact of current fiscal policies (i.e. whether individual members of future generations face a higher lifetime net tax burden compared to members of currently living generations) it is, however, necessary to go beyond this macroeconomic perspective. For this reason the aggregate amounts, which have to be taken over by currently living and future generations, are broken down to the microeconomic level, resulting in the average remaining net tax payments members of the different generations $k$ still have to pay over their remaining lifetime (i.e. the generational accounts).

$$
\left[\sum_{s=t}^{k+D} n_{s, k}\left(1+r_{s}\right)^{t-s}-\sum_{s=t}^{k+D} p_{s, k}\left(1+r_{s}\right)^{t-s}\right]
$$

"A generational account is the present value of the per capita net taxes that a generation will pay for the rest of its life under the assumed fiscal policy." ${ }^{2}$

Note that the definition of the generational accounts implies that only newborns in year $t$ and individual members of future generations directly compare,

\footnotetext{
${ }^{2}$ Gokhale, Page and Sturrock (1998[13]), pp.4-5
} 
as both still have their whole lifetime ahead of them. Hence, the intergenerational imbalance of current fiscal policies in the context of 'Generational Accounting' is revealed in the different magnitudes of the generational accounts of newborns in year $t$ and future generations. A larger generational account for future generations therefore signifies that current fiscal policies cannot be maintained into the future without putting an 'extra' burden onto them.

Cardarelli, Kotlikoff and Sefton (1999[7]) have produced the first set of generational accounts for the United Kingdom based on the fiscal year 1997. Using the above-described methodology of 'Generational Accounting' they have shown that fiscal policies in the UK are rather sound, as future generations are expected to face only slightly higher generational accounts compared to newborns in 1997. For reasons of comparability with these earlier results this study adopts the same methodological approach in constructing a new set of generational accounts for the base-year 2001. ${ }^{3}$ As in the aforementioned earlier study the baseline scenario is calculated assuming a $1.75 \%$ growth and a $5 \%$ discount rate. The corresponding results for male generations in the UK are:

\begin{tabular}{l|cc} 
& $\mathbf{1 9 9 7}$ & $\mathbf{2 0 0 1}$ \\
\hline Newborns & 49,290 & 54,520 \\
Future Generations & 60,823 & 53,350
\end{tabular}

Table 1: Generational accounts with base year $1997^{4}$ and base year 2001 in 2001 pound Sterling.

From table 1 it can be seen that regulatory changes in the tax and benefit system as well as changed population projections have slightly altered the picture. Although the difference is very small, future generations are expected to pay less lifetime net taxes compared to newborns in 2001. In the context of 'Generational Accounting' this constitutes a slight improvement in the intergenerational balance of current fiscal policies. Fiscal policies in the United Kingdom could therefore be maintained into the future without putting an 'extra' burden on future generations.

Although the results (table 1) for the United Kingdom are encouraging, a global comparison of generational accounts suggests that nearly all industrialised countries with mature welfare states do shift a substantial public debt towards future generations through the institutions of the state.[14] Therefore it has been argued on the basis of the results obtained by 'Generational Accounting':

"Unless currently living members of these countries pay more in net taxes or unless these countries dramatically cut their purchases of goods and services, future Americans, Japanese, and Germans will face dramatically higher rates of lifetime net taxation." 5

\footnotetext{
${ }^{3}$ For a more detailed methodological treatment see Cardarelli, Kotlikoff and Sefton $(1999[7])$

${ }^{4}$ Data taken from Cardarelli, Kotlikoff and Sefton (1999[7])

${ }^{5}$ Kotlikoff , Leibfritz and Auerbach (1999[14]), p.100
} 
This quote suggests that if current fiscal policies are maintained, future generations will have to spend a big share of their generated economic value on benefits which currently living generations enjoy. Note however that this conclusion drawn from the results based on the original methodology of 'Generational Accounting' is only true when no private intergenerational transfers are made. If, to the contrary of the above, economic agents either care about the welfare of their siblings (e.g. altruistic behaviour) or face insecurity with regard to their life expectancy, private intergenerational transfers occur, which compensate future generations for the financial burden left to them through the institutions of the state. Generational accounts, which only take into account public transfers, are therefore misleading, as either intentional or unintentional private intergenerational transfers might compensate future generations for the public debt, which is shifted to them. This highlights the fact that "the usefulness of generational accounts as a summary of the budget's impact on the intergenerational distribution of private consumption and on aggregate consumption lives or dies with the validity of the strict life-cycle model of household consumption" ${ }^{6}$, which says that economic agents only save for consumption at later stages of their life and consequently do not leave private wealth to future generations.

For this reason it can be argued that generational accounts are uninformative as regards the budget's intergenerational impact as soon as decision horizons intentionally or unintentionally differ from those postulated by the life-cycle model of consumption.

Concluding, as 'Generational Accounting' is based on the strict life-cycle model and, thus, contains the long-term revenue and expenditure prospects of governments, it gives a more accurate account of the government's indebtedness. However as it is only based on the inter-temporal budget constraint of the government it disregards the changes in private saving and consumption behaviour, which are decisive in order to understand the intergenerational impact of the public ledger. It therefore is to be seen as a serious improvement in estimating the 'real' fiscal burden of government policies, but leaves unresolved the debate about the question in how far this indebtedness has harmful consequences for the economy in the long run. Hence, the procedure has to take into account private intergenerational flows in trying to capture the effect current fiscal policies have on aggregate demand, on private savings and the intergenerational net tax burden.

In the next section a methodological way is proposed which enables to account for private intergenerational flows in the context of 'Generational Accounting'. It can be called the 'Net-Wealth of Society' approach. This approach starts from the perspective that the private wealth accumulated so far will be passed on to future generations. Rather than accounting solely for the net wealth of the government, as done in the original methodology of 'Generational Accounting', the approach will define and calculate the net wealth of society, which will consequently be used to determine the financial burden that current and future generations will have to face.

\footnotetext{
${ }^{6}$ Buiter (1996[6]), p. 605
} 


\section{The 'Net-Wealth of Society' - The extended model}

The negative implications of the public ledger very much depend on the question whether future generations are privately compensated for the public debt left to them. Therefore, policy models that assume there is no linkage between generations except through the state bear little resemblance to reality. An accounting system, which highlights the allocation of the public burden among working and retired population as well as future generations, needs to include both, the public and private ledger. Hence it is necessary to account for the financial flows that privately link generations in the context of generational accounting. [6]

In contrast to the original methodology of generational accounting, the extended model proposed here is based on the budget constraint of the society as a whole, not only on the budget constraint of the government. It aims at including net private wealth in addition to the net government wealth, in order to get a better understanding of the true fiscal stance of society as a whole. Net private wealth, in this respect, is the accumulated net asset by the private households over the past plus the amount of wealth that currently living generations are still expected to accumulate over their remaining lifetime assuming a constant propensity to consume. Note that the assumption of a constant propensity to consume in the extended model is the private sector equivalent to the assumption about unchanged fiscal policies in the original methodology of 'Generational Accounting'.

Adding net private wealth, as defined above, to the net public wealth in the budget constraint of the government gives the 'Net Wealth of Society'. In analogy with equation 2 the government budget constraint, which integrates the 'Net-Wealth of Society', can be expressed as:

$$
\begin{aligned}
\sum_{s=t}^{\infty} G_{s}\left(1+r_{s}\right)^{t-s} & =\left[\sum_{s=t}^{k+D} L_{s, k} n_{s, k}\left(1+r_{s}\right)^{t-s}-\sum_{s=t}^{k+D} L_{s, k} p_{s, k}\left(1+r_{s}\right)^{t-s}\right] \\
& +\left[\sum_{s=t+1}^{\infty} L_{s, k} n_{s, k}\left(1+r_{s}\right)^{t-s}-\sum_{s=t+1}^{\infty} L_{s, k} p_{s, k}\left(1+r_{s}\right)^{t-s}\right] \\
& +\left[\sum_{s=t}^{k+D} S_{s, k}^{p}\left(1+r_{s}\right)^{t-s}+W_{t}^{p}+W_{t}^{g}\right]
\end{aligned}
$$

So that

$$
\left[\sum_{s=t}^{k+D} S_{s, k}^{p}\left(1+r_{s}\right)^{t-s}+W_{t}^{p}+W_{t}^{g}\right]=N W S_{t}
$$


Note:

$W_{t}^{p}=$ Net private wealth accumulated by past and current generations

$S_{s, k}^{p}=$ Private savings of generation $k$ in all current and future years $s$

$W_{t}^{g}=$ Net government wealth

$N W S_{t}=$ Net wealth of society in base year $t$

The 'Net-Wealth of Society' $\left(N W S_{t}\right)$ is defined as the sum of the net government wealth $\left(W_{t}^{g}\right)$ plus the net private wealth, which past and current generations have accumulated so far, $\left(W_{t}^{p}\right)$ plus the savings that generations already alive in year $t$ are still expected to set aside over their remaining lifetime $\left(\sum_{s=t}^{k+D} S_{s, k}^{p}\left(1+r_{s}\right)^{t-s}\right)$. The financial net lifetime burden of future generations is therefore calculated taking into consideration the total stock of net wealth, which past and living generations are expected to pass on to future generations. The remaining savings of all generations already alive in 2001 can be estimated as the difference between the incomes that they are still expected to earn over their remaining lifetime and the remaining lifetime consumption:

$$
\sum_{s=t}^{k+D} S_{s, k}^{p}\left(1+r_{s}\right)^{t-s}-\left[\sum_{s=t}^{k+D} Y_{s, k}^{p}\left(1+r_{s}\right)^{t-s}+\sum_{s=t}^{k+D} C_{s, k}^{p}\left(1+r_{s}\right)^{t-s}\right]
$$

Note:

$Y_{s, k}^{p}=$ Average income of generation $k$ in all current and future years $s$

$C_{s, k}^{p}=$ Private savings of generation $k$ in all current and future years $s$

As a part of the net wealth of society, net private wealth should take account of the real and financial wealth of private households. Real wealth is defined as the sum of durable consumer goods as well as real estate net of loans. Financial wealth on the other hand comprises life insurance, money holdings, securities and shares, deposits and accumulated assets in private pension schemes.

The amount of net personal wealth in the United Kingdom in 2000 has been estimated at 4535 billion pounds.

\begin{tabular}{c|ccc} 
& Assets & Liabilities & Net Wealth \\
\hline Personal Wealth & 5,145 & 610 & 4,535
\end{tabular}

Table 2: Personal wealth estimates for 2000 (Amounts: $£$ thousand million) ${ }^{7}$

${ }^{7}$ The data are derived from those published in the July 2002 edition of Financial Statistics and the 2002 Blue Book of United Kingdom National Accounts, adjusted for those assets held by non-profit-making bodies such as charities and to mid 2000 values. (Source: Inland Revenue) 
Adjusting the personal wealth $\left(W_{t}^{p}\right)$ for growth in order to receive an estimate for 2001 gives $4,614 £$ thousand million. Extrapolating income and consumption patterns into the future and discounting them back to the base year $t$ gives an estimated $1,143 £$ thousand million in remaining lifetime savings of generations already alive in year $t$.

Using these values in the context of the extended methodology gives generational accounts for male newborns in 2001 and future generations of:

\begin{tabular}{l|c} 
& $\mathbf{2 0 0 1}$ \\
\hline Newborns & 54,520 \\
Future Generations & $-157,179$
\end{tabular}

Table 3: Extended generational accounts including the 'Net-Wealth of Society' ${ }^{\prime}$

From table 3 it can be seen that if current fiscal rules are maintained into the future and the propensity to consume of generations already alive in the base year 2001 does not change, future generations will face a negative generational account (-157 thousand pounds), which literally means they receive transfers instead of paying taxes (i.e. negative taxes).

Whenever generational accounts of future generations are smaller in magnitude as compared to generations already alive in the base year $t$ the original model suggest that some wealth of currently living generations is transferred to future generations through the institutions of the state. Hence future generations can enjoy the same level of public benefits at a lower 'tax' price. In the extended model the conclusion that future generations receive transfers either through the institutions of the state or through private intergenerational links that exist in reality holds. Correspondingly, combining the results from the first and the second part of the analysis shows that future generations in the United Kingdom are expected to receive a considerable private financial transfer from past and currently living generations. As the public generational account (table 1) based on the original methodology of 'Generational Accounting' was balanced and the integration of private financial flows between generations into the methodology (table 3) has led to highly negative generational accounts for future generations, it becomes clear that individual members of future male generations in the United Kingdom receive a net private transfer of about 200 thousand pounds.

\section{Conclusions and unresolved issues}

This paper points out that 'Generational Accounting' is an interesting way to estimate the burden of current policies upon future generations. In its approach, however, it seriously overestimates the net-costs imposed on the future by ignoring private intergenerational transfers. Taking private intergenerational transfers into account using what we called the 'Net-Wealth of Society' approach,

\footnotetext{
$5 \%$.

${ }^{8}$ The annual growth rate is assumed to be $1.75 \%$ and the annual discount rate is
} 
allows us to conclude that for the UK future generations will receive rather than pay; this means that future generations receive far more in transfers from current economic prosperity than what is left to be paid for the expenditures on the social well-being of the current generations. More popularly said: there are enough funds to finance the current government expenditures including the costs of caring for the growing number of elderly persons. ${ }^{9}$ What is true for the UK is partially also true for other advanced capitalist economies although the financial burden of especially the pension system highly differ. Estimates for Germany, for example, using slightly different methods resulted in the same type of conclusions although the net transfers to future generations are estimated to be relatively smaller for that country. [16]

This, however, does not imply that the policy problem of financing government expenditures including the dramatic demographic transition in Europe is resolved. The 'Net-Wealth of Society' approach, as 'Generational Accounting', is basically a technique that estimates economy-wide costs and transfers; it does not provide any information on distributional issues. Whether the wealth with future generations will be distributed in a way that it can be mobilized through taxes, is an open question. With the ability guaranteed, the willingness to pay becomes the crucial issue, potentially leaving the state with a definite risk of being unable to serve its debt. This brings policy research in this area to the point where 'taxability' becomes the main issue when deciding whether current government expenditures and welfare provisions are financially sustainable in the long term.

The theoretical issues raised by this paper are puzzling. This paper emphasizes the magnitude of private intergenerational transfers and their relevance for estimating the debt burden on future generations. ${ }^{10}$ The 'Net-Wealth of Society' approach does not, however, provide any information on the welfare effects of these flows. The welfare effects of these flows depend on the degree of altruism in society, i.e. the degree to which the Ricardian equivalence theorem holds. Ricardian equivalence is only realized if the future generations are privately compensated for the public debt left to them, which in turn is conditioned by the underlying transfer (bequest-) motives.

If economic agents are fully altruistic or face insecurity with regard to their life expectancy, as mentioned earlier, the private flows, which the analysis has identified, are compensatory. Private transfers between generations, though, can also take place without the existence of altruistic behaviour or insecurity with regard to life expectancy. Bernheim, Shleifer and Summers (1986[3]) have indicated that private intergenerational transfers could be used "to purchase a commodity from the child" 11 . In this case private transfers merely constitute a payment in exchange of a commodity provided by younger generations. They do not compensate for higher taxes in the future. Hence the predominance

\footnotetext{
${ }^{9}$ This is an empirical confirmation of what Buiter (1996[6]) concluded from a theoretical assessment of 'Generational Accounting'.

${ }^{10}$ Kotlikoff and Summers (1998[15]) provided first estimates for the significance of private intergenerational transfers for the USA.

${ }^{11}$ Bernheim, Shleifer and Summers (1986[3]), pp. 151-182.
} 
of a strategic bequest or transfer motive would bring the analysis back into the boundaries of the life-cycle model of consumption and thus the original methodology of 'Generational Accounting'.

From this perspective, it can be argued that the original methodology of 'Generational Accounting', by ignoring private intergenerational transfers, represents the one extreme case of a strict life-cycle model. The 'Net-Wealth of Society', on the other hand, represents the other extreme by implicitly assuming altruistic behaviour and/or insecurity about ones' remaining lifetime and excluding the idea that (some of the) private intergenerational transfers are actually payments made for commodities. This paper therefore by no means allows drawing conclusions about the welfare implication of current government expenditures. Making some progress in answering this question requires the consideration of a general equilibrium model. The reality will most probably be situated between the two extremes, but the authors are pretty pessimistic on the possibility of qualitatively assessing the predominance of either altruistic (and/or risk aversion) or strict life cycle behaviour wherein every generation 'pays its own bills' (except of what is left over in government wealth or debt).

\section{List of Equations}

(1) Intertemporal government budget constraint

(2) The public financial burden of future generations - The residual approach

(3) Ind. generational accounts of generation $k$ already alive in base year $s$

(4) Government budget constraint including the 'Net-Wealth of Society'

(5) 'Net-Wealth of Society'

(6) Remaining savings of generations already alive in base year $t$

\section{References}

[1] Ando, Albert and Franco Modigliani (1963), The "Life Cycle" Hypothesis of Saving: Aggregate Implications and Tests, The American Economic Review, 53(1): pp. 55-84.

[2] Barro, Robert J. (1974), Are Government Bonds Net Wealth?, The Journal of Political Economy, 82(6): pp. 1095-1117. 
[3] Bernheim, B. Douglas and Andrei Shleifer and Lawrence H. Summers (1986), The Strategic Bequest Motive, Journal of Labour Economics, 4(3): pp. 151-182.

[4] Bernheim, B. Douglas (1989), A Neoclassical Perspective on Budget Deficits, Journal of Economic Perspectives, 3(2): pp. 55-72.

[5] Bonin, Holger (2001), Generational Accounting: Theory and Application, Population Economics, Heidelberg: Springer-Verlag Berlin.

[6] Buiter, Willem H. (1996), Generational Accounts, Aggregate Savings and Intergenerational Distribution, Economica, 64(256): pp. 605-626.

[7] Cardarelli, Roberto, Laurence J. Kotlikoff and James Sefton (1999), Generational Accounting in the UK, in NIESR Discussion Papers.

[8] Cardarelli, Roberto, Laurence J. Kotlikoff and James Sefton (2000), Generational Accounting in the UK, The Economic Journal, 110(467): pp. 547-74.

[9] Diamond, Peter A. (1965), National Debt in a Neoclassical Growth Model, The American Economic Review, 55(5): pp. 1126-1150.

[10] Eisner, Robert and P. J. Pieper (1984), A New View of the Federal Debt and Budget Deficits, American Economic Review, 74: pp. 11-29.

[11] Eisner, Robert (1989), Budget Deficits: Rhetoric and Reality, Journal of Economic Perspectives, 3(2): pp. 73-93.

[12] Gokhale, Jagdeesh and Laurence J. Kotlikoff Alan J. Auerbach (1991), Generational Accounts - A meaningful Alternative to Deficit Accounting, NBER Working Paper Series, ed. NBER. Vol. Working Paper No. 3589, Cambridge, Ma: National Bureau of Economic Research.

[13] Gokhale, Jagdeesh, R. Page and J. Sturrock (1998), Generational Accounts for the United States: An Update, National Bureau of Economic Research

[14] Kotlikoff, Laurence J., Willi Leibfritz, Alan J. Auerbach (1999), Generational Accounting Around the World, National Bureau of Economic Research: Chicago and London

[15] Kotlikoff, Laurence J. and Lawrence H. Summers (1981), The Role of Intergenerational Transfers in Aggregate Capital Accumulation, The Journal of Political Economy, 89(4): pp. 706-732.

[16] Lüth, Erik (2001), Private Intergenerational Transfers and Population Aging, 1st ed., Contributions To Economics, ed. M.B. Werner A. Müller, Heidelberg: Physica Verlag. 